\title{
Conversational Identity Work in Everyday Interaction
}

\author{
Peter Mclnnes ${ }^{\mathrm{a}}$ * \\ aUniversity of Strathclyde Business School \\ 199 Cathedral Street, \\ Glasgow, G4 oOU \\ Scotland
}

peter.mcinnes@strath.ac.uk

Telephone +44 (0)1415536064

Fax $\quad+44(0) 1515566971$

Sandra Corlett ${ }^{\mathrm{b}}$

${ }^{b}$ Newcastle Business School

Northumbria University

City Campus East,

Newcastle-Upon-Tyne, NE1 2SW

England

sandra.corlett@northumbria.ac.uk

Telephone +44 (o)191 2274920

Fax $\quad+44(0) 91912274190$

* corresponding author 


\title{
Conversational Identity Work in Everyday Interaction
}

\begin{abstract}
Increasing numbers of studies are identifying 'identity work' in research participants' efforts to establish, maintain, deny or change the identity positions being ascribed to self and other. However, as authors variously emphasize how far identity is negotiated between people, on the one hand, and how far it is determined by prevailing discourses and local ideational notions of who people are, on the other, we are arguably no closer to understanding how identity work gets done in everyday organizational talk. To address this issue we present a conceptualisation of identity work that contrasts these two aspects. Through an analysis of talk in a mundane, everyday, meeting we identify and illustrate five prevalent identity work forms. Taken together, these forms and the conceptualisation represent an important first-step toward developing a more nuanced understanding of the different ways in which people's identities are engaged in, reproduced through, and altered by their participation in their everyday routine organizing practices.
\end{abstract}

Keywords: Identity, identity work, interaction, organizational talk, positioning, social obligations, discourse, positioning, meetings 


\section{Introduction}

As a social phenomenon constructed and communicated through language, the identity of individuals can be considered as an unfinished 'project' that remains open to contestation and change over time (Ainsworth \& Hardy, 2004; Antaki \& Widdicombe, 1998). Rather than a fixed quality of individuals, identity is something that must be strived for, justified and defended on an on-going basis in everyday interaction. Consequently, the notion of "identity work" has gained currency as a headline term capturing the various processes and tactics through which people attempt to form, repair, maintain or revise their identity (Kärreman \& Alvesson, 2001; Snow \& Anderson, 1987; Svenningsson \& Alvesson, 2003). The identity work literature has focussed on varying ways in which individuals seek to establish their identity positions. Some have chronicled the way that individuals position themselves relative to, and in turn are positioned by, the ideational notions of who they should be and how they should act that are informed both by societal discourses (A. Davies \& Thomas, 2008; Kornberger \& Brown, 2007; Linstead \& Thomas, 2002) and local debates on what one's job entails (Simpson \& Carroll, 2008; Watson, 2008). The way that people position themselves relative to these ideational/discursive issues contrasts with the work of others who emphasize the interpersonal negotiation of identity. These authors consider the relational positioning of self, relative to the other, that individuals or groups employ in establishing their identity constructions (Ezzell, 2009; Lutgen-Sandvik, 2008). While the vibrancy of the field suggested by this variety is welcome, there is a question of how these two aspects contribute to identity work in everyday talk. In this respect, it is noticeable that the extant literature is predominantly derived from interview-based accounts of the workplace. With notable exceptions (e.g. Kärreman \& Alvesson, 2001; Down and Reveley, 2009), and despite calls for research that does so (Coupland, 2001), little attention has fallen upon what might be considered 'naturally occurring' conversation (Silverman, 2007), that is the 'organizational talk-in-motion' (Alvesson et al., 2009, p.21) of everyday workplace interaction. As it is within everyday talk that identities are evoked, drawn upon and reconstructed (Antaki \& Widdicombe, 1998), the literature lacks an account of how identity work is undertaken in conversation as individuals seek to lay blame, confirm status, justify themselves etcetera. This is an important issue for the concerns addressed in this special issue, because it risks losing sight of the dynamic way in which, within organizational talk, 'quests for identity intersect, intermingle and interact with organizational activity' (Kärreman \& Alvesson, 2001, p. 60). 
We begin to address the literature's omission by contributing an understanding of how identity work is undertaken in everyday organizational talk. In pursuing this aim, we derive a conceptualisation of identity work built upon a synthesis of the different aspects of identity work suggested by the literature. This contrasts the degree to which ideational/discursive issues are emphasized in the identity position being asserted, with the degree of relational positioning latitude afforded to self or other in co-constructing identity. The conceptualisation of identity work this offers helps us to understand the field and opens the way to examining what is going on in organizational talk. Our empirical analysis of the identity work being undertaken in an everyday, interdepartmental meeting yields five illustrative identity work forms. These forms allow us to explore the way in which the two aspects of identity work blend together as interactants debate the issues and each other's roles within the practices of the organization.

The paper is structured in the following manner. We first review the literature, showing how the two aspects of identity work are reflected in the literature and how the other contributions to this special issue relate to the conceptualisation of identity work we develop by treating these aspects as axes. Within the review, we draw on the notion of positioning as a way of understanding how, in talk, individuals construct their identities by labelling self and other, drawing on hierarchical role and organizational responsibilities, making use of specific personal pronouns etc. Details are then given of the empirical study that we draw upon in this paper, the analytical procedure we followed and a description of the meeting we focus upon. Our findings unpack the prevalent identity work forms employed in the meeting, illustrating how self and other are positioned in each case. The discussion explores the way in which identity work involves a subtle exchange of duties, rights and obligations as interactants seek to establish, contest and maintain identity positions. In concluding the paper, we examine the implications of our work and indicate potentially fruitful directions for future research.

\section{Identity Work}

The growth in work examining 'identity work' is associated with the rise to prominence of the view that identity is socially constructed through language and formed and shaped through the relationships we have to ourselves and each other (Ainsworth \& Hardy, 2004; Butler, 2005; Gergen, 2009). The fragility and open-ended nature of identity means that identity work can be found where 'people [are] engaged in forming, repairing, maintaining, strengthening or revising the 
constructions that are productive of a sense of coherence and distinctiveness' (Svenningsson \& Alvesson, 2003, p. 1165). The breadth with which this definition is drawn directs our attention to the important, if often implicit, role identity plays in much of organizational experience. Research has, in this respect, allowed us to understand that individual identity faces challenges from changing expectations within the organizational context (Svenningsson \& Alvesson, 2003; Thomas \& Linstead, 2002), but also from the behaviour of others towards the self (Lutgen-Sandvik, 2008; Sims, 2003). To maintain an identity one might well have to position oneself differently depending upon the audience (A. Davies \& Thomas, 2008), but one might equally seek consistency in order to modify the set of relations that sustain a particular self-identity (Down \& Reveley, 2009).

Whilst this gives a flavour of this productive field, it also serves to highlight that the term 'identity work' is being used to cover a range of circumstances involving different rhetorical approaches to achieve particular identity outcomes. One way of conceptualising the varying approaches taken in the literature is by recognising that identity work involves an ideational/discursive aspect, on the one hand, and an interpersonal aspect on the other. The ideational/discursive aspect acknowledges that identity work takes place within the structural arrangements of organizations and the multiplicity of organizational and societal discourses that affect interactions. On the other hand, identity work's interpersonal aspect can be seen to involve an attempt to alter the relationship between individuals. Such a distinction is somewhat synthetic as there are, of course, no pure types here and identity work can be seen to ordinarily involve some combination of these interpersonal and ideational/discursive aspects. So, for example, the supervisor in Down and Reveley's (2009) study, who is attempting to change his identity through identity work, is implicitly asking those around him to accept a change in their relationship as he rhetorically employs his job title, experience and organizational discourses to reposition himself relative to them. This said, these aspects are variously emphasized, and it is useful, ahead of developing a conceptualisation of these different combinations, to consider each aspect more fully.

The literature reflects the ideational/discursive aspect of identity work in a variety of ways. Perhaps the most prevalent literature in this area concerns the way that the self's relation with particular ideas, and ideals, leads to reflexive questioning, and on-going debate, concerning how one should think and act in prevailing circumstances. Such identity work might well evolve from the discursive resources arising within the social context (Kornberger \& Brown, 2007; Kuhn, 2006; Svenningsson 
\& Alvesson, 2003). Equally, however, societal discourses may directly and indirectly inform identity work (Ainsworth \& Hardy, 2004; Ybema et al., 2009). Discourses such as gender or race, for example, can be seen to provide resources that help individuals establish themselves as distinctive and valued (Essers \& Benschop, 2007; Ezzell, 2009), whilst, equally, delimiting what can be said and done by an individual (Rumens \& Kerfoot, 2009). Davies and Thomas (2008), for example, examine the forces shaping the identity positions of community police officers. Here officers draw upon societal and organizational discourses that place value upon work in the community. Yet they equally account for themselves in terms of an underlying masculinist discourse which prefers measures of effectiveness, such as arrests, over 'pink and fluffy' policing. Identity work is not, then, solely about the use of discursive resources to establish valued identity positions, but can also be experienced as tensions between different social duties and rights associated with being a particular-type-of-individual. In this sense identity work is associated with the regulation of identity to the extent that one might be constrained in how one might act, or how one might be viewed (Ainsworth \& Hardy, 2009; Alvesson \& Willmott, 2002). As Watson (2008) highlights, identity work is equally associated with the 'structural conditions' that support, and prevail upon, individual actors. Job titles and role responsibilities are not immutable features, however, but are ideational matters shaped by prevailing organizational politics and broader discursive notions of what that job should entail (Simpson \& Carroll, 2008; Svenningsson \& Alvesson, 2003; Thomas \& Linstead, 2002). For example, Clarke, Knights and Jarvis (2012), in this special issue, illustrate the potency of discourses such as new public management and managerialism within UK universities and the readiness of academics to comply with performative requirements. The resulting 'identity struggle' over who one should be is acknowledged as being one which must be undertaken discursively on an on-going basis with different audiences (Alvesson, 2010; Down \& Reveley, 2009; Svenningsson \& Alvesson, 2003). Less well represented, however, are the tensions that this struggle brings to conversational identity. In this respect, it is not simply that the way one describes one's self might be contested, but that counter descriptions, drawing on different discursive resources, invoke an array of potentially contradictory duties, rights and obligations to which one is expected to respond (Burr, 2003; B. Davies \& Harré, 1999). Hence an actor might perceive themselves to be relatively 'free' to choose amongst the available identity positions made available by discourse as they describe what their own, or another's, job entails. At the other extreme, in being called to account, they might find that the duties being invoked oblige them to speak from a particular subject position (Butler, 2005). Recent work has begun to acknowledge 
that discussions occurring between hierarchical levels can involve subtle, and not so subtle, efforts to use identities to open up, or close down, dialogue (Thomas, Sargent, \& Hardy, 2011). Beyond this, however, the literature has tended to focus on the identity's role in the reproduction of ideational/discursive issues (Clarke, et al., 2012; Llewelyn, 2004), rather than the role being played by social obligations in the conversational positioning of self and other.

As Holloway (1984) notes, during social interaction an individual not only 'takes up positions' made available by discourse, s/he also 'positions oneself' in relation to other people. Accordingly, our second aspect of identity work, the interpersonal, builds on the notion that who an individual "is" lies in the on-going negotiation of relative self and other identity (Beech, 2008). If only as an ideal type, this interpersonal aspect of identity work might be observed in conversations that reflect an open-ended dialogic exploration of alternative identity positions (Gergen, 2009). In such circumstances, self and other might be said to afford each other unlimited latitude in the relational positions being offered to each other. That is, statements implying who the self (or other) "is" invite and are responsive to the other's response. This said, workplace identities are more typically co-constructed, negotiated and contested through the on-going dialogues that intertwine personal and professional identities with the narrative of the organizations that employ them (Watson, 2009). Consequently everyday conversational identity work is as likely to involve the confirmation of identities (Kärreman \& Alvesson, 2001) and attempts to change identities by redefining relationships (Down \& Reveley, 2009) as it is unfettered dialogue. One way in which dialogue might be closed down is through constructing fixed identity positions. Research has, for example, highlighted the way in which identity positions can be predicated upon the rejection of the values and behaviours associated with a specific other (Garcia \& Hardy, 2007; Snow \& Anderson, 1987). Such 'defensive othering' (Ezzell, 2009) asserts self and other identity as being unchanging and can become entrenched in self-reinforcing 'anti-dialogic' identity positions (Beech, MacPhail, \& Coupland, 2009). The continuum, extending between dialogue and antidialogue, suggests that organizational talk might involve identity work in which self and other are offered varying degrees of latitude to define their identities relative to each other. However, prior to this special issue, in which Ybema, Vroemisse and van Marrewijk (2012) provide an excellent analysis, there has been no consideration of how different degrees of relational positioning latitude might be represented within organizational talk. 
To summarise, we have traced two aspects of identity work in the literature. In examining the way in which the ideational/discursive aspect of identity work is presented, we have argued that individuals might perceive themselves to be under varying degrees of obligation to speak from a particular identity position by the social obligations implicit to the prevailing interactional context. These range from instances where actors feel relatively free from obligations, through to those instances where they perceive themselves to be constrained. On the other hand, in its interpersonal aspect, we have suggested that identity work can involve self and other granting to each other different degrees of relational positioning latitude to shape the identity positions implied by their relationship. Here again, these range from instances where self-other positioning is relatively free and open to dialogic exploration, through to those circumstances when the identity of self and other are relatively constrained. Combining these two continua (see figure 1) affords us the opportunity of exploring further the variations that exist in the different treatments of 'identity work' in the literature.

\section{[Insert Figure 1 here]}

We can see how different treatments might fit on this figure if we consider other contributions to this special issue. Mallett and Wapshott (2012, pp. 13-14), for example, recounts Lisa's struggle with the 'creative constraints' of her job at UKDesign in contrast to the freedoms of her recent university training and her (discursively formed) expectations of the duties of a 'junior designer'. Therefore this study chronicles identity work that is constrained by ideational/discursive issues but also latterly by a relational struggle when, by undertaking work viewed as 'corporate' and 'uncreative' by her colleagues, Lisa finds herself positioned as part of an 'outgroup' (Mallett \& Wapshott, 2012, pp. 14-15).

Contrasting identity work is presented by Ybema, Vroemisse and van Marrewijk (2012, p.10) who explain how Aim members' 'ideological predilection to show respect or 'humanness" was part of a deliberate but freely undertaken commitment to smooth away cultural and hierarchical distinctions from their 'Southern' partners. Furthermore, by consciously acknowledging these 
social obligations, the Aim members afforded a high degree of relational positioning to their partners by inverting the usual 'we normal, you strange'-type of self-other talk (Ybema et al., 2012, p.9).

Beech, McLeod, Cochrane and Greig (2012) discuss identity tensions that exist for members of an opera company. These include for Bella who does not want to 'sound like a diva' but simultaneously acts in a 'highly diva-like' manner (p.17), for instance, by distancing herself from the 'lesser singers in the chorus' (Beech et al., 2012, p.11). Although Bella is afforded a high degree of latitude to construct her diva identity relative to others, she 'apparently feels she has to' act in this way (Beech et al., 2012, p.17), implying that she is fulfilling some social obligation. Beech et al.'s $(2012$, p.17) identification of tensions internal to the person that may 'pull in different directions simultaneously' and elicit 'a balancing of responses' is consonant with our argument of the varying degrees to which relational positioning latitude and social obligations aspects combine, often in tension. We have indicated these tensions by the bi-directional axes arrows within our framework.

While this framework might prove helpful in understanding the diverse identity work literature, it is its potential as a means of understanding conversational identity work that we wish to explore here. The suggestion being that conversational identity work might variously emphasize either, or more likely a combination, of our two aspects as individuals seek to establish, maintain, undermine or change the identities of self and other. This not only provides a way to summarise the field, it offers the prospect of answering calls for research that examines 'the complex interconnection between talk and identity as research should be concerned with how communication simultaneously expresses and creates who we are' (Coupland, 2001, pp. 1105-1106). However, despite talk's importance to the process of identity construction, the identity work literature has, somewhat surprisingly, remained restricted to Kärreman \& Alvesson's (2001) analysis of conversational identity work, within a meeting of 'newsmakers'. This, however, focuses on the way that, in general, a shared sense of identity was confirmed through conversational identity work.

This is not to say that identity's role in organizational talk has not been considered. Studies informed by conversation analysis have acknowledged identity's role within the talk-in-motion (Boden, 1994) of organizational life and 'real time' activities of people at work (Llewellyn \& Burrow, 2007). Llewellyn and Spence's (2009, p. 1419) study, for example, illustrates how the 'ordinary activities of the job interview' reveal members' orientations to recruitment practice, including 
definitions of acceptable conduct and identities. However, they do not go on to consider how individuals orient to, or variously draw on, aspects of identity in the interview activities and recruitment practices. Samra-Fredericks' (2003, p.159) conversation analytic study of strategizing discusses the use of personal pronouns such as "I" and "you" as relational-rhetorical resources to establish an identity through positioning self and others. However, Samra-Fredericks (2003) goes no further admitting that the 'strategists' assembly of a viable identity is ... purposefully skirted around' (p.169) in the paper.

Although we do not adopt conversation analysis methods, our fine-grained analysis of naturally occurring talk offers the potential to make a distinctive contribution to conversational identity work. To illustrate this, and to provide the basis for further discussion, we draw from the analysis of an organizational meeting the prevalent forms of identity work.

\section{Methods statement}

The paper's empirical material consists of an analysis of identity work undertaken during a regular monthly meeting within a major photoprocessing retailer, Snap (the company and research participant's names have been changed to maintain confidentiality). This mirrors the approach taken in one of the foundational papers in the field of conversational identity work (Kärreman \& Alvesson, 2001). The wider study that this is drawn from saw fifteen of the organization's Headquarters staff involved in an array of interview and observation data gathered over a nine month study of the organization. This material furnished us with a detailed background understanding that helped us in interpreting the unfolding events within the meeting data we focus on here ( see also Thomas, et al., 2011). The meeting was one of three observed by the lead author. In all three instances, attendees were interviewed afterwards to ascertain what they thought was going on, why things had been said and whether people would follow-through on the commitments they had made in the meeting. Initial findings were then played back to attendees and their efforts to 'correct' the researcher's interpretations provided further insight into the-waythings-are-around-here (Beech, Hibbert, Maclntosh, \& McInnes, 2009). Of the three meetings, the first, a departmental meeting of IT staff, was not tape recorded and as much as copious field notes were kept, these did not fulfil this article's need to examine the subtleties of identity work performed within talk-in-motion. The second meeting, the review of a shop's operations by the IT manager and an Area Sales Manager, was tape recorded, but background noise in the shop made 
transcription and the checking of intonation virtually impossible. Therefore, it is the third meeting, between members of Central Services and the IT department, which we draw upon in this paper. The transcripts are in many ways unremarkable, they resonate with the mundane discussions and debates witnessed by the lead author in similar meetings, and there is little to suggest that they are not wholly representative of other meetings within the organization. For us, however, the transcripts provided a rich source of data in which identity, if not being directly invoked, was providing, and being shaped through, identity-as-context (Zimmerman, 1998).

As analytical approach, we first broke the transcript into narrative "segments" (Riessman, 1993), sequences of exchanges around an issue, from which, latterly, we drew the extracts featured in our findings. Next, we examined these segments to discern the identity positions being adopted by actors, those being set up for the other, and the reactions of self and other to these positions (Beech \& Sims, 2007). We then combined this examination of how interpersonal relations were being performed and shaped through interaction with an analysis of what was going on, what was being taken for granted, and how this local-talk related to the discursive context. This involved us cross-checking the post-interview commentaries with the meeting transcripts examining how identities were being enacted in the meeting through the positioning of self and other relative to ideational/discursive notions. Perhaps the most obvious example of this came in the way hierarchical roles were variously emphasized as individuals sought to shape what should happen, but there were equally more subtle references to societal level managerial discourses as well as prevailing organizational discourses on change and integration. By considering how such acts reflected the ideational/discursive and interpersonal aspects, a 'patterning' (Potter \& Wetherell, 1987, p. 168) emerged that, when mapped onto our axes, began to cluster around the five identity work forms presented in the findings section.

The aim of our data presentation and interpretation is not to derive theoretical generalisations about conversational identity work and its varying forms from what we'd readily acknowledge to be a limited amount of data. Instead, we offer 'relatively concrete illustrations of processes' (Watson, 2003, p.174) of conversational identity work deployed by the meeting participants, and our 'interpretive insights' (Cunliffe, 2008, p. 126) into the 'contextualised data' (Elliott, 2005, p.26). Recreating in text the subtleties of relational context and tone that adds so much to conversation is difficult (see Samra-Fredricks, 2004). For this reason we have added 'stage notes' in square 
brackets to passages where tone is critical to understanding what is going on. Further, the way in which we complement our selected data with examples of other academics' research which places different emphases on interpersonal/ relational and ideational/discursive aspects of identity work highlights the potential 'pragmatic use' (Riessman, 1993, p. 68) of the framework as an interpretative aid. Before describing the findings we provide brief details of the meeting.

\section{The meeting}

The meeting featured here was one of a series of regular meetings between the IT Department and the Central Services departments within the company's headquarters. Although various departments were invited, it was predominantly members of the Finance function who attended these meetings. This particular meeting, for instance, saw Hannah, the Financial Accountant, and three others responsible for different areas of the accounts, meeting with the Head of IT, Bob, and one of his staff, Harry. (The research participant's names have been changed to maintain confidentiality.) The following table summarises the actors mentioned in the transcripts.

\section{[Insert Table 1 here]}

The meeting takes place in a general purpose office-cum-meeting space and people assemble around a large table with the IT personnel on one side of the table and the Finance people on the other. The researcher sits in the corner farthest from the door with a tape recorder. Already knowing the researcher will be present, people nod and smile as they enter the room. By this stage in the research they are well past making the usual jokes about being recorded and the premeeting chat concerns the time pressure that the Finance staff is under to fulfil the monthly reporting cycle.

Hannah chairs the meeting, although Bob, who is more senior, frequently assumes this role. The agenda, which Hannah has pulled together somewhat hastily, is a list of outstanding IT issues across Central Services. That Bob, almost immediately, labels this 'our whinge list' is indicative of the relatively combative atmosphere in the meeting and the different meanings attached to it by 
participants. For the IT people, the meeting was the Finance staff's opportunity to displace pressure and frustration onto the IT department. The agenda was, after all, a list of problems. For the Finance people, IT's slightly dismissive attitude simply reinforced the view that the meeting was an arena in which "we" (Finance) held "them" (IT) to account for their ineptitude. These opposing views caused a palpable tension within the meeting and, as a result, social relations were unsettled, and discussions often invoked role boundaries, responsibilities and, by implication, the identities ascribed to self and other.

\section{Findings}

Engaging with the transcripts of this everyday meeting revealed a rich source of instances where the identity of participants was in-play. There was a genuine dynamism that fluctuated between participants engaging in open discussions of what should be done by whom and the direct ascription of who actors were and what they should do. By focussing on what discursive business was done in exchanges, and how it was being undertaken, we were able to discern five identity work forms. Each reflected a different emphasis upon the aspects of identity work found in the literature. So, for example, performative identity work afforded little latitude for alternative selfother positions, often because actors were insistent that particular job responsibilities were adhered to. By contrast confirmatory identity work could be found in exchanges where social obligations seemed unimportant, and a high degree of latitude was given in how the other might respond. In between these, three further identity work forms, controlling, reconciling and negotiating, were traced that referenced or inferred some social obligation impinging upon selfother identity but, to different degrees, afforded self and other latitude to negotiate identity positions. The findings can be summarised in the following figure (fig. 2).

\section{[Insert Figure 2 here]}

Before examining each in turn, we would reiterate that our aim is to illustrate the diverse ways in which identity work is undertaken in everyday organizational talk. The forms we draw from our data are tentative, open-ended and leave areas for development through further research. The top 
and bottom corners, for instance, are blank as not all the possibilities were strongly reflected in our data set. There is, however, much that is new here as previous research has neither acknowledged, conceptualised, nor examined identity work's varied forms.

\section{Performative Identity Work}

Performative identity work occurred where the individual felt under an obligation to enact a particular identity because of prevailing personal, social or institutional pressures. We use the term 'performative' here in the Lyotardian sense of being drawn to enact a particular role in order to satisfy the perceived expectations of those present (Lyotard, 1979). An example from the literature might be the site director of an R\&D cell studied by Svenningsson \& Alvesson (2003) who resents, but is obliged to perform for those she reports to, a facilities management role she characterises as 'cell janitor'. Here too performative identity work was found where social obligations seemed to press upon what should be said. However, as much as performative identity work reflected the duty to respond in a particular way, it also featured in passages where the rights of an individual to expect certain behaviours of the other were being emphasized. Both are illustrated in the discussion of the most contentious agenda item handled during the meeting, the delayed processing of credit card transactions. Having arrived late to the meeting Wilma almost immediately pursued Bob on the laxity of his staff's handling of the situation. Performative identity work began around the account of past actions:

Wilma: [professional, but forceful] Basically what I'm looking for is a reassurance that this isn't going to happen and somebody's not going to sit on a query like this for thirty five days with $£ 37,000$ lying there.

$B o b$ : [slighty tired sounding] He didn't sit on it, there were conversations going backwards and forwards but it was/

Wilma: [more forcefully] Well he did sit on it because the money wasn't in the bank until thirty five days after that day.

Wilma begins the exchange, drawing upon the duties associated with professional accounting to maintain systemic integrity in recording transactions. She makes explicit the extent of the failed standards of professionalism of an unspecified 'somebody' and Bob's obligation, as her supplier, to ensure the situation does not reoccur. Bob's move to a specific 'he' betrays the fact that this is a long-standing argument and that he is clearly aware of the circumstances of this episode. Wilma appropriates the move to a specific individual, but 
rejects Bob's account of this person's behaviour. For her, this individual and Bob have an unequivocal duty to act in a professional manner. Bob then defends his staff:

Bob: [exasperated] We had to wait until the following week to see if it had been processed. And then we sent it again and/

Wilma: [no less forcefully] Sorry, you don't actually have to wait a week to see if the file's been processed because our contacts at [processing centre], they can tell us the next day.

In this extract, Wilma's emphatic use of 'sorry' (not expressed in an apologetic manner) and 'actually' in conjunction with 'you' constrains Bob's relational latitude. She also begins to specify the expected duties of IT; to process the files in a timely manner. In the final exchange, this expectation is accentuated as Wilma moves from describing what should be done to prescribing the actions of an imagined other.

Bob: ... But eh, it could happen again, that the same thing happens.

Wilma: [still forcefully] There's absolutely no reason why it should Bob. I mean seriously, if this is highlighted then if it's to fix that day then they look the next day, if it's not there then they look again and fix it. I mean my personal opinion is somebody looks at this, a conversation flies about and that's it left, they think it's done. They should be then going to check that it is done.

As these extracts suggest, performative identity work was more than a one-off statement of role, duty and obligation. Rather it involved an on-going process of pursuing particular identity positions by insisting upon where duties and obligations should fall. Wilma's insistence and clarity in setting out the obligations of the other, through expressions such as 'absolutely' and 'seriously' and nonnegotiable timescales for activities, leaves Bob little room for manoeuvre. It is also noticeable that, as the interaction progresses, she shuts off his attempts to justify or defend the laxity in the procedures and processes followed. Additionally, Wilma's reference to Bob's name seemed to be calling him personally to account (Butler, 2005). In this respect, making sure the same thing did not happen again became an obligation that Bob was under pressure to fulfil. It is this sense of having to speak from a particular role/task based identity position that marks this out as performative identity work. 


\section{Controlling Identity Work}

Controlling identity work occurred in situations where people were afforded little latitude for negotiating the relationship between the self and other. Like performative identity work, controlling identity work might involve attempts to prescribe who someone was or what actions should be undertaken. However, unlike performative identity work, these assertions were equivocal or were interpreted as such by the interactants. As in Alvesson and Willmott's (2002) case of the 'angry worker', controlling identity work sanctions redefinition of the situation and resistance or defence by the self in the face of perceived attack. These features are illustrated by our second extract, taken from a discussion of a current problem about file transfer which soon turned to the long-standing issue of tracing and reclaiming 'lost' transactions from the credit card processing company.

Bob: Have we got any outstanding at the moment?

Betty: [answering abruptly] Yes, this file that was put on hold because everybody was busy... See at the top here. We kept coming to you last year and sometime/ Bob: [shocked] last year?!

Betty: oh yeah, we have outstanding queries going way back ... and there was a lot of other data as well. That is like missing sales and things like that.

Bob: [quietly, aside to Harry] I'm not enjoying this

$B o b$ : Is this the pink folder? Is this the pink folder? Hannah is th/ Hannah:[slightly disinterested] Is it the pink folder?

Betty: This is prob/ Yes it's the pink folder. And there was my spreadsheet to go and it was kind of started then stopped then started then passed from people to people.

Harry: What was the one that the temp came in to take...?

Betty: That was part of it.

Harry: [same shocked tone as Bob earlier]That was part of it?

Betty: That was a part of it.

Bob: That was two pages.

Betty: Yep, that was a small part of it. [There's a pause. Bob and Betty look at each other and laugh]

Bob: ...Right. Shall we get the temp back again? I think that's best.

Betty: So you're going to get a temp in to look.

Bob: I'm sure that's all it needs to be honest

Both Finance's pre-meeting interview and IT's post-meeting interview confirmed the longevity of 'the pink folder' issue. Although, as in the previous case of performative identity work involving Bob and Wilma, Betty's intention might be to assert the significance of the situation and make Bob accountable for the outstanding queries, their hierarchical differential gives Bob greater relational latitude and the power to undermine Betty's attempts. As both Finance and IT knew the situation, 
Bob's claim of surprise ('last year?') and ignorance ('is this the pink folder?') appears somewhat disingenuous. However, because of Betty's junior hierarchical status relative to Bob, Bob's positioning of himself in this way invokes a right, as a manager, to have things explained. This draws Betty into an exchange where further ignorance can be expressed by IT whilst social convention prevents her from voicing any suspicion that Bob is being disingenuous. Bob's responses can be read, at least in part, as intended to defuse Finance's attempts to construct him as failing in his managerial duties and to repair his vulnerability in the face of the implied attack. Harry's reference to the temp, brought in by Bob to address the backlog, could further be interpreted as an attempt to help his manager 'maintain face' (Goffman, 1959, 1967). However, Bob's comment about the extent of the work previously done reveals his knowledge of events and the almost scripted pattern of the discussion precipitates tension-relieving laughter. The relational positional dynamics and the co-constructed identity work occurring in this interaction are, therefore, markedly different to those in the illustration of performative identity work. Betty is not in a hierarchical position to prescribe to Bob what he should do. However, Bob accepts the controlling effect of the partially undertaken duty and obligation by proposing to deploy another temp. Thus, in addition to illustrating controlling identity work, this extract highlights how context and the meaning 'given' to a particular social interaction by the interactants influences identity work outcomes.

\section{Reconciling Identity Work}

This form of identity work occurs where interactants seek to construct identities that are complementary to the relational positioning of the other and to the social obligations that both parties have acting upon them. One might read, for example, those in the early stages of workplace bullying, in Lutgen-Sandvik's (2008) study, to be undertaking reconciling identity work when they seek to understand the behaviour of the bully and modify their own behaviour in order to avoid triggering bullying episodes. Alternatively, in Kornberger \& Brown's (2007) study, the consultants' struggle to enact an ethical policy in their relation with clients and each other might be seen as reflecting the reconciliation of identity position relative to social obligations and interpersonal relationship.

In the meeting, what was distinctive about this form of identity work was that the actors modified their stance. In the first extract above, for example, Bob's unsuccessful attempts to explain the 
delayed processing circumstances can be read as invitations to Wilma to enter into reconciling identity work that will co-construct less antagonistic identities. However, in that particular series of exchanges, Wilma did not accept Bob's self-positionings and, instead, insisted on her definition of the situation (Burr, 2003). An example of successful reconciling identity work can be found in the debate between Bob and Hannah over who should buy identification labels for the cash registers.

Bob: Should we not just go out and buy some? You should just go out and buy some. Hannah: No, I thought you were.

Bob: Naw, I'm not buying labels. That's what accounts people/ Hannah: Why would we go and buy them?

Bob: You want the asset register. I don't care where they are. Hannah: hmmm

Bob: How about I give you the catalogue?

Hannah: OK, you give me the catalogue and I will find some labels.

On the surface this is not an IT issue and Bob's initial switch from 'we' to 'you' signals something of a slip from a collective (i.e. the IT department) that risks being interpreted as accepting responsibility for buying the labels to a clarification of the expectation placed on the other (i.e. the 'accounts people'). In replying to Hannah's counter-claims, Bob positions the task with Finance, first by defining them directly (Alvesson \& Willmott, 2002) and then insisting that it is their desire for a comprehensive record of assets (required for audit purposes) that is at issue. This downplays other IT-related reasons why such a register might be needed such as providing a base for recording maintenance or upgrade information. However, rather than insisting on the constraining and implied subordinate self-other positioning and associated duty that 'accounts people buy labels', Bob backtracks by offering to supply a suitable catalogue. He, therefore, grants latitude to Hannah in how to respond. As Bob indicated in his pre-meeting interview, he had a good working relationship with Hannah and, perhaps, felt an obligation towards her. His softening of position creates a dialogue in which social obligations might be reconciled and the relations between, and the identities of, self and other remain relatively undisturbed.

\section{Negotiating Identity Work}

Negotiating identity work occurred where the relationship between interactants was relatively open, and social obligation, whilst present, did not prohibit change in identity positions. This type of identity work might be seen to reflect Gergen's (2009) notion of identity emerging from a free and fluid dialogic exploration of the relationship between self and other. In practice, however, 
such dialogue built upon existing understandings of who the individual was (Beech, 2008). In the meeting, this form of identity work often involved the exploration of new situations such as the introduction of new technology. An example of this occurred in the discussion of the way stock reporting was being handled.

Hannah: yeah, Tim only told me about it this morning that's why it's just suddenly there. I said 'did you talk to IT?' and he said 'no' so that's why it hasn't been done. [laughs, but no-one else joins in] Harry: When do you need it done? Hannah: as soon as possible 'cause we haven't got any period four data in and period four's meant to be shutting today ... So em, first thing next week if that's when the temp starts we'll need him to look at that.

Bob: What have we got? Is it just built on the (analytic software) stuff? Harry: That's what I don't know. I don't know what the data source is. I know it comes from the summary information from the actual lab production things.

Hannah: It's from the lab traffic reports that they fax. That's where I tie the figures in to. Harry: Yeah, I'll actually have a look at that and find/ we'll maybe even be able to do that already for the past two weeks.

Hannah: It's not just the last two weeks, it's from the beginning of period four. We're in five now so from the beginning of April.

Harry: Yeah, however the infrastructure has only been in place for the last two weeks that'll maybe allow us to do that.

Hannah: So we might not.

Bob: ... Is that any good to you?

Hannah: It'll have to be, won't it?

In contrast to our previous extracts, the extent of shared definition of the situation is marked. Both Finance and IT accept the structural arrangement of the organization, with Tim as the senior Management Accountant imposing this job as a priority. Despite the urgency generated by the company's reporting timetable, this is not an instance where Hannah, as Bob indicated in his postmeeting interview, exhibited the tendency to project pressure onto IT. Instead she is vague in stating the time scale and appreciates IT's resource implications in taking on this new task. When discussing how the new report might be generated, each speaks from role-based experience and knowledge and respects the role boundaries of the other. Thus the relationship between interactants remains free and open. Responsibility for completing the task is clearly shared and the underlying process of exploring and testing out each other's expectations, that happens through the whole extract, is exemplified by the concluding exchange. 


\section{Confirmatory Identity Work}

Confirmatory identity work was found in circumstances where the social context obligations had low levels of influence on the interaction and some, or indeed a great deal, of latitude was afforded in the relationship between self and other. This form of identity work allowed both the self and other to maintain their self-definition within their shared context and involved little apparent active or conscious identity work. In many senses it is the form of identity work being undertaken by Kärreman \& Alvesson's (2001) newsmakers, mundane conversation that speaks from and reinforces the identity positions of the interactants. In our study, discussion of replacement credit card readers, conducted on the basis of equals, confirmed the respective identity positions, of the IT personnel as the hardware experts, and the accountant as the banking processes expert.

Wilma: But have [IT supplier] come up with any chat about the new readers? Bob: Eh, yeah. Their view is don't do it yet because there's only one supplier for the hardware.

Harry: We've got until next year, so.

Wilma: yeah, true. You get a reduced rate off the banks if you're compatible. The [bank] are trying to bring the machine out, but it's a standalone machine which is no use to us as we're looking for a build onto the tills. But yeah, we do have until next year. Bob: [IT Supplier] are saying that everybody will make these things but not this year... but when they do it gets cheaper.

In many ways, what is marked about this extract is its neutrality, particularly given the animosity that usually reverberated between the two departments and its representatives. Bob offers information from the perspective of the supplier of hardware while Wilma comments on the financial aspects of the change. Bob, Wilma and, to an extent, Harry introduce information about what is required and when, but this is not treated as an intrusion into the other's construction of self as knowing expert or as an imposition of duty or obligation. Rather the date of introduction and the type of machine are topics that serve to confirm that both parties know what is happening and are in control of the situation.

As much as confirmatory identity work was uncontentious, there were often back-stories to the interactions provided in the post-meeting interviews. For example, in this instance, Bob admitted that the cost and complexity of installing new readers 'utterly terrifies me'. His intention in responding to Wilma's broaching of the subject was to defer the issue 'until next year'. So while confirmatory identity work might recreate and offer a semblance of security to identity, interaction 
was rarely entirely 'free' and unselfconscious. There may well be a degree of instrumental control being exercised. Our discussion will pick up on the intentionality interpreted as being 'behind' identity work as we explore the different forms of identity work found in the meeting and what these suggest about the identities being co-constructed in interaction.

\section{Discussion}

Our aim in this article is to provide a more nuanced understanding of how identity work gets done in mundane everyday organizational talk. Our critique of extant work on conversational identity work highlighted that it had not engaged with the turn-by-turn negotiation of identity that typifies organizational talk. Where previous work in the area had identified one type of conversational identity work (Kärreman \& Alvesson, 2001), our work has begun the process of unpacking the spectrum of possible ways in which self and other can position themselves and each other in interaction. Discerning performative, controlling, reconciling, negotiating and confirmatory identity work forms in a transcript of an organizational meeting helps us understand the dynamic, creative way in which the ideational/discursive and interpersonal aspects of identity work are variously emphasized as individuals seek to establish, maintain, challenge or deny the identity positions of self and other.

The findings help us understand how ideational/discursive issues inform interaction. In this respect, it was noticeable that meeting participants rarely, if ever, engaged in the free-flowing, dialogic exploration of identity positions suggested by Gergen (2009). This is, perhaps, because the nature of the meeting - to discuss issues between two areas of the business - and the nature of the items - things IT hadn't done - brought with them assumed identity positions and power relations that informed what was said and done in the meeting. We would, however, disagree with the view that these underlying factors reduced all interaction to one type of conversational identity work (Kärreman \& Alvesson, 2001). Rather these were issues that could be, alongside and in concert with others, salient at a given point in the conversation. For example, the exploration of what should happen in negotiating identity work is informed by underlying assumptions about IT's and Finance's relative areas of knowledge, and differs from the 'pink folder' debate in controlling identity work because of the insistence upon role responsibilities and the position of Bob in the hierarchy. This latter example also serves to illustrate that while positional power shaped what could, and could not, be said, this was not, as some have found, a one-sided matter in which Bob 
determined the course of interaction (Thomas, et al., 2011). Instead our findings suggest that while both role and hierarchical position bring powers and capacities that enable an actor to undertake or insist upon certain actions, they carry with them duties and obligations that are available to the other to support their claims (Burr, 2003; B. Davies \& Harré, 1999). At their most pronounced these obligations can, as performative identity work shows, constrain individuals to speak from a particular position. However, while we would accept this as evidence of the regulatory effects of (in this instance managerial) discourse (Alvesson \& Willmott, 2002), the effect of discourses did not delimit the forms of identity work being undertaken (Clarke, et al., 2012). Rather we see the ongoing debates on what discourses might mean for identity construction (A. Davies \& Thomas, 2008; Kornberger \& Brown, 2007), to be enacted within the web of interpersonal relations that shape who self and other are.

As much as dialogue was constrained by ideational/discursive matters, the findings also evidence the resilience afforded to it by the interpersonal aspect of identity work. For instance, even when the most combative examples of performative identity work might suggest Finance were engaged in 'defensive othering', the right-ness of their own identity position was reinforced, by constructing the other as unreasonable and consistently incompetent (Ezzell, 2009; Sims, 2005). The meeting never reached the impasse suggested by 'anti-dialogic' identity positions (Beech, MacPhail, et al., 2009). Instead, even in circumstances where identity was being challenged or undermined (Sims, 2003; Svenningsson \& Alvesson, 2003), examples such as the fixed asset register discussion showed the way in which reconciling identity work opened up the conversation to alternative identity positions. At one level we might, as Ybema et al. (2012) do, attribute this to research participants' commitment to 'humanness', but for us it has more to do with the inter-relationship between self and other and between who 'we are' in the meeting and whether, and how, things get done in the organization. That is, continuing to pursue Bob in the way suggested by performative identity work does not alleviate the backlog of errors and, therefore, a more conciliatory identity work form, such as controlling identity work, typically followed. It was not so much that in so doing the rights, duties and obligations of the situation might be more malleable, but there was certainly a sense of the temporal shift from past-present versions of who one should be, and what one should have done, to what needed to happen in the future and, crucially, who was going to do what. This research, therefore, allows us to consider conversational identity work not simply as a reflection of 'structural circumstances' (Watson, 2008), but as the on-going process through which 
organizational practices are linked to the process of negotiation through which interactants position each other relative to each other and to the ideational/discursive issues that they drew upon as they constructed their identities. Hence, for us, identity work is not just a bi-product of organizational life; it is woven into the very fabric of organizing.

\section{Conclusions}

While, as a term, identity work has enjoyed both longevity and increasing popularity, it is clear that work is still required for it to be established as a field of study. In developing a conceptualisation of identity work, this paper has, we hope, provided a basis for thinking with greater clarity what is meant when we invoke the term. The specific contribution of this paper lies in its examination of the identity work being performed in mundane organizational talk. This has been accomplished by considering positioning as a resource associated with duties, rights and obligations being coconstructed as interactants position each other within talk. We have, through empirical analysis, drawn out prevalent identity work forms found in an everyday organizational meeting that might be taken up by future research. In this respect, the variety of identity work forms we identified extends the literature on conversational identity work (Kärreman \& Alvesson, 2001) by revealing something of the varied ways in which identity might be shaped within organizational talk.

We believe that our framework represents an important development for the identity work literature, moving the field towards a more nuanced understanding of conversational identity work. However, our illustrative identity work forms are derived from a single meeting within one organization. Research may refine the framework, producing finer-grained labels and completing those areas of the figure where we lacked the data to develop forms, or it could, indeed, draw out different aspects of identity work in order to build a richer picture of what is happening in interaction. Further, we have limited ourselves in this paper to identifying illustrative forms of identity work. In so doing we have set aside the potential dynamism that might emerge between them. Future research might engage with what happens when self and other employ contrasting, as well as complementary, forms of conversational identity work. Alternatively, research could consider the type of identities being constructed by organizational talk and how in-meeting and out-of-meeting identities differ. 


\section{References}

Ainsworth, S., \& Hardy, C. (2004). Discourse and Identities. In D. Grant, C. Hardy, C. Oswick \& L. Putnam (Eds.), The Sage Handbook of Organizational Discourse (pp. 153-173). London: Sage.

Ainsworth, S., \& Hardy, C. (2009). Mind over Body: Physical and psychotherapeutic discourses and the regulation of the older worker. Human Relations, 62(8), 1199-1229.

Alvesson, M. (2010). Self-doubters, strugglers, storytellers, surfers and others: images of selfidentities in organization studies. Human Relations, 63(2), 193-217.

Alvesson, M., \& Willmott, H. (2002). Identity Regulation as Organizational Control: Producing the appropriate individual. Journal of Management Studies, 39(5), 619-644.

Antaki, C., \& Widdicombe, S. (1998). Identity as an achievement and as a tool. In C. Antaki \& S. Widdicombe (Eds.), Identities in Talk (pp. 1-14). London: Sage.

Beech, N. (2008). On the Nature of Dialogic Identity Work. Organization, 15(1), 51-74.

Beech, N., Hibbert, P., Maclntosh, R., \& McInnes, P. (2009). "But I thought we were friends" Life cycles and Research Relationships. In S. Ybema, D. Yanow, H. Wels \& F. H. Karmsteeg (Eds.), Organizational Ethnography: Studying the Complexities of Everyday Life (pp. 196-214). London: Sage Publications.

Beech, N., MacPhail, S., \& Coupland, C. (2009). Anti-dialogic Positioning in Change Stories: Bank robbers, saviours and peons Organization, 16(3), 335-352.

Beech, N., \& Sims, D. (2007). Narrative Methods for Identity Research. In A. Pullen, N. Beech \& D. Sims (Eds.), Exploring Identity: Concepts and Methods (pp. 288-301). Basingstoke: Palgrave MacMillan.

Boden, D. (1994). The Business of Talk: Organizations in action. Cambridge, UK: Polity Press.

Burr, V. (2003). Social constructionism (2nd ed.). London: Routledge.

Butler, J. (2005). Giving an Account of Oneself. New York, NY: Fordham University Press.

Clarke, C. A., Knights, D., \& Jarvis, C. (2012). A Labour of Love? Academics in business schools. Scandinavian Journal of Management, $X X(X X)$.

Coupland, C. (2001). Accounting for Change: A discourse analysis of graduate trainees' talk of adjustment Journal of Management Studies, 38(8), 1103-1119.

Cunliffe, A. L. (2008). Orientations to Social Constructionism: Relationally Responsive Social Constructionism and its Implications for Knowledge and Learning. Management Learning, 39(2), 123-139.

Davies, A., \& Thomas, R. (2008). Dixon of Dock Green Got Shot! Policing identity work and organizational change. Public Administration, 86(3), 627-642.

Davies, B., \& Harré, R. (1999). Positioning and personhood. In R. Harré \& L. van Langenhove (Eds.), Positioning theory: Moral contexts of intentional action (pp. 32-52). Oxford: Blackwell.

Down, S., \& Reveley, J. (2009). Between Narration and Interaction: Situating first-line supervisor identity work. Human Relations, 62(3), 379-401.

Essers, C., \& Benschop, Y. (2007). Enterprising Identities: Female entrepreneurs of Moroccan or Turkish origin in the Netherlands. Organization Studies, 28(1), 49-69. 
Ezzell, M. B. (2009). "Barbie Dolls" on the Pitch: Identity work, defensive othering, and inequality in women's rugby. Social Problems, 56(1), 111-131.

Garcia, P., \& Hardy, C. (2007). Positioning, similarity and difference: narratives of individual and organizational identities in an Australian university. Scandinavian Journal of Management, $23(4), 363-383$.

Gergen, K. J. (2009). Relational Being: Beyond self and community. New York, N.Y.: Oxford University Press.

Goffman, E. (1959). The Presentation of Self in Everyday Life (Penguin ed.). Harmondsworth: Penguin.

Goffman, E. (1967). Interaction Ritual: Essays in face-to-face behavior. Garden City, NY: Doubleday.

Hollway, W. (1984). Gender difference and the production of subjectivity. In J. Henriques, W. Hollway, C. Urwin, C. Venn \& V. Walkerdine (Eds.), Changing the subject: psychology, social regulation and subjectivity. (pp. 223-261).

Kärreman, D., \& Alvesson, M. (2001). Making Newsmakers: Conversational identity at work. Organization Studies, 22(1), 59-89.

Kornberger, M., \& Brown, A. D. (2007). 'Ethics' as a discursive resource for identity work. Human Relations, 6o(3), 497-518.

Kuhn, T. (2006). A "Demented Work Ethic" and a "Lifestyle Firm": Discourse, identity, and workplace time commitments. Organization Studies, 27(9), 1339-1358.

Linstead, A., \& Thomas, R. (2002). "What Do You Want from Me?"A Poststructuralist Feminist Reading of Middle Managers' Identities. Culture \& Organization, 8(1), 1.

Llewellyn, N., \& Burrow, R. (2007). Negotiating identities of consumption: insights from conversation analysis, pp. In A. Pullen, N. Beech \& D. Sims (Eds.), Exploring identity: Concepts and methods, (pp. 302-315). Basingstoke: Palgrave Macmillan.

Llewellyn, N., \& Spence, L. (2009). Practice as a members' phenomenon. Organization Studies, $30(12), 1419-1439$.

Llewelyn, N. (2004). In Search of Modernization: The negotiation of social identity in organizational reform. Organization Studies, 25(6), 947-968.

Lutgen-Sandvik, P. (2008). Intensive Remedial Identity Work: Responses to workplace bullying trauma and stigmatization. Organization, 15(1), 97-119.

Lyotard, J.-F. (1979). The Postmodern Condition: A report on knowledge (G. Bennington \& B. Massumi, Trans.). Manchester: Manchester University Press.

Mallett, O., \& Wapshott, R. (2012). Mediating ambiguity: Narrative identity and knowledge workers. Scandinavian Journal of Management, $X X(X X), x \times X-X X X$.

Potter, J., \& Wetherell, M. (1987). Discourse and Social Psychology: Beyond attitudes and behaviour. London: Sage.

Riessman, C. K. (1993). Narrative analysis. Newbury Park, CA: Sage.

Rumens, N., \& Kerfoot, D. (2009). Gay men at work: (Re)constructing the self as professional. Human Relations, 62(5), 763-786. 
Samra-Fredricks, D. (2004). Managerial elites making rhetorical and linguistic 'moves' for a moving (emotional) display. Human Relations, 57(9), 1103-1143.

Silverman, D. (2007). A very short, fairly interesting and reasonably cheap book about qualitative research. London: Sage.

Simpson, B., \& Carroll, B. (2008). Re-viewing 'Role' in Processes of Identity Construction Organization, 15(1), 29-50.

Sims, D. (2003). Between the Millstones: A narrative account of the vulnerability of middle managers' storying. Human Relations, 56(10), 1195-1211.

Sims, D. (2005). You Bastard: A narrative exploration of the experience of indignation within organizations. Organization Studies, 26(11), 1625-1640.

Snow, D. A., \& Anderson, J. (1987). Identity Work Among the Homeless: The verbal construction and avowal of personal identities. American Journal of Sociology, 92(6), 1336-1371.

Svenningsson, S., \& Alvesson, M. (2003). Managing Managerial Identities: Organizational fragmentation, discourse and identity struggle. Human Relations, 56(10), 1163-1193.

Thomas, R., \& Linstead, A. (2002). Losing the Plot? Middle managers and identity. Organization, 9(1), 71-93.

Thomas, R., Sargent, L. D., \& Hardy, C. (2011). Managing Organizational Change: Negotiating meaning and power-resistance relations. Organization Science, 22(1), 22-41.

Watson, T. J. (2008). Managing Identity: Identity Work, Personal Predicaments and Structural Circumstances. Organization, 15(1), 121-143.

Watson, T. J. (2009). Entrepreneurial Action, Identity work and the use of multiple discursive resources. International Small Business Journal, 27(3), 251-274.

Ybema, S., Keenoy, T., Oswick, C., Beverungen, A., Ellis, N., \& Sabelis, I. (2009). Articulating Identities. Human Relations, 62(3), 299-322.

Ybema, S., Vroemisse, M., \& van Marrewijk, A. (2012). Constructing identity by deconstructing distinctiveness: Building partnerships across cultural and hierarchical divides. Scandinavian Journal of Management, $X X(X X)$, $x x X-X x X$.

Zimmerman, D. H. (1998). Identity, Context and Interaction. In C. Antaki \& S. Widdicombe (Eds.), Identities in Talk (pp. 87-106). London: Sage. 
Figure 1. The two aspects of identity work illustrated by the papers in this Special Issue

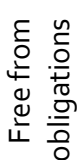

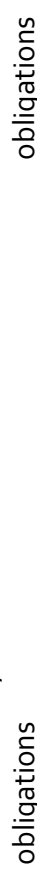

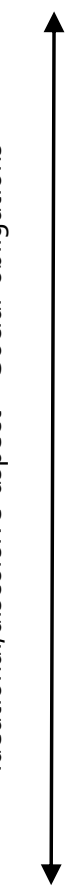

Wapshott and

Mallett - Lisa's

identity work
Ybema et al. Aim members' identity work

Beech et al. Bella's identity work
Constrained self - other positioning
Interpersonal aspect - Relational positioning latitude

Free self - other positioning 
Figure 2: Illustrative identity work forms




Table 1: The meeting actors

\begin{tabular}{|l|l|l|}
\hline \multicolumn{1}{|c|}{ Name } & Department & \\
\hline Bob & IT & Head of IT \\
\hline Harry & IT & IT technician who reports to Bob \\
\hline Hannah & Finance & Financial Accountant \\
\hline Wilma & Finance & Head of the Sales Ledger \\
\hline Betty & Finance & $\begin{array}{l}\text { Assistant to Wilma, leaves when Wilma } \\
\text { comes into the meeting }\end{array}$ \\
\hline Tim & Finance & Management Accountant (not in attendance) \\
\hline
\end{tabular}

